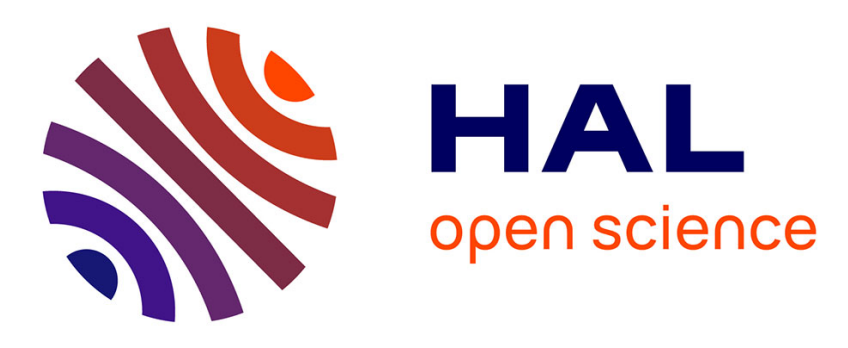

\title{
Direct Aldolization of Unprotected Fructose to Bio-Based Surfactants
}

\author{
Biwen Zhu, Nicolas Duguet, Guo-Rong Chen, Marc Lemaire
}

\section{To cite this version:}

Biwen Zhu, Nicolas Duguet, Guo-Rong Chen, Marc Lemaire. Direct Aldolization of Unprotected Fructose to Bio-Based Surfactants. ACS Sustainable Chemistry \& Engineering, 2018, 6 (9), pp.1169511703. 10.1021/acssuschemeng.8b01953 . hal-02128565

\section{HAL Id: hal-02128565 \\ https://hal-udl.archives-ouvertes.fr/hal-02128565}

Submitted on 1 Jun 2021

HAL is a multi-disciplinary open access archive for the deposit and dissemination of scientific research documents, whether they are published or not. The documents may come from teaching and research institutions in France or abroad, or from public or private research centers.
L'archive ouverte pluridisciplinaire HAL, est destinée au dépôt et à la diffusion de documents scientifiques de niveau recherche, publiés ou non, émanant des établissements d'enseignement et de recherche français ou étrangers, des laboratoires publics ou privés. 


\title{
Direct Aldolisation of Unprotected Fructose to Bio-Based Surfactants
}

\author{
Biwen Zhu, ${ }^{a}$ Nicolas Duguet, ${ }^{*}, a$ Guo-Rong Chen, ${ }^{b}$ Marc Lemaire ${ }^{*}, a$
}

${ }^{a}$ Univ Lyon, Université Claude Bernard Lyon 1, CNRS, INSA-Lyon, CPE-Lyon, Institut

de Chimie et Biochimie Moléculaires et Supramoléculaires, ICBMS, UMR 5246, Equipe CAtalyse, SYnthèse et ENvironnement (CASYEN), Bâtiment Lederer, 1 rue Victor Grignard, F-69622 Villeurbanne cedex, France.

${ }^{b}$ Key Laboratory for Advanced Materials \& Institute of Fine Chemicals, School of Chemistry and Molecular Engineering, East China University of Science and Technology, 130 Meilong Road, Shanghai 200237, P. R. China

e-mails: nicolas.duguet@univ-lyon1.fr, marc.lemaire.chimie@univ-lyon1.fr

KEYWORDS. Aldolization, aldehydes, fructose, bio-based surfactants

ABSTRACT. A new alkylation mode of fructose was developed by direct aldolization of unprotected fructose with fatty aldehydes as alkylating agents. The reaction occurs in the presence of a base in a mixture of water $/ \mathrm{EtOH}$ at $60^{\circ} \mathrm{C}$ under microwave irradiation. Trimethylamine was found the most effective base for the aldolization of fructose with short chain aldehydes (C4-C8) while better results were obtained with $\mathrm{K}_{2} \mathrm{CO}_{3}$ in association with tetrabutylphosphonium bromide (TBPB) for long chain aldehydes 
(C8-C12). The corresponding alkylated fructose were obtained as mixture of 3 main tautomers (the $\beta$-pyranoid form being the predominant isomer) and were isolated with $31-46 \%$ yield. These aldolization products were also reduced under hydrogen to give the corresponding alkylated heptaols with $84-96 \%$ isolated yields.

\section{INTRODUCTION}

The chemical transformation of renewable biomass is currently the subject of intense research for the preparation of bio-based chemicals that are promised to (partially) replace fossil-based products. ${ }^{1-4}$ Carbohydrates represent about $75 \mathrm{wt} \%$ of the available biomass and their transformation into valuable products offer great challenges from the synthesis point of view. ${ }^{5,6}$ The conversion of aldohexoses - with D-glucose as archetype - has been extensively studied but, comparatively, little attention has been devoted to the valorisation of ketohexoses. ${ }^{7}$ D-Fructose is the most abundant ketoses in Nature where it is found as a monomer in inulin and levans or in association with glucose in sucrose. Fructose can be produced by enzymatic hydrolysis of the aforementioned sources. ${ }^{8}$ Alternatively, it can also be produced by catalytic isomerisation of glucose ${ }^{9-12}$ through Lobry de Bruyn-van Ekenstein mechanism. ${ }^{13}$ One the one hand, fructose is mainly produced as high-fructose syrup (HFS) that is used as sweeteners in food and beverage industries. ${ }^{14}$ Moreover, it can also be used to produce, mainly via enzymatic catalysis, ${ }^{15}$ levans and fructooligosaccharides (FOS), that have found applications as prebiotics in food, nutrition and medical sciences. ${ }^{16}$ On the other hand, fructose can be used as a cheap renewable material for the production of bio-based specialty chemicals. 
For example, the dehydration of fructose affords 5-hydroxymethylfurfural $(5-\mathrm{HMF})^{17-20}$ that is a key platform molecule towards the production of 2,5-furanedicarboxylic acid (2,5-FDCA), ${ }^{21}$ a key building-block for the production of biobased polymers. ${ }^{22-24}$ Fructose can also be used for the synthesis of renewable surfactants. ${ }^{25,26}$ To date, only two families of fructose-based surfactants have been developed, namely, fructose esters and alkyl fructosides. Fructose esters can be obtained by direct esterification of fructose with a wide range of fatty acids (Scheme 1, a). Enzymatic methods employing immobilized lipases are usually preferred over chemical ones as enzymes usually offer better selectivities towards the formation of the monoesters and work under mild conditions (ambient temperature, water as solvent). ${ }^{27-33} \mathrm{O}$-alkyl fructosides have also been developed as biobased surfactants but they have been by far less studied than their glucoside analogues (Scheme 1, b). Alkyl fructosides can be produced by trans-glycosylation of sucrose in the presence of alcohols. $^{34-37}$ Alternatively, octyl fructosides were prepared by direct acid- ${ }^{38}$ or iodine-catalysed ${ }^{39}$ Fischer glycosylation of fructose with octanol leading to a mixture of $\beta$-D-fructopyranoside and $\alpha$ - and $\beta$-D-fructofuranosides.

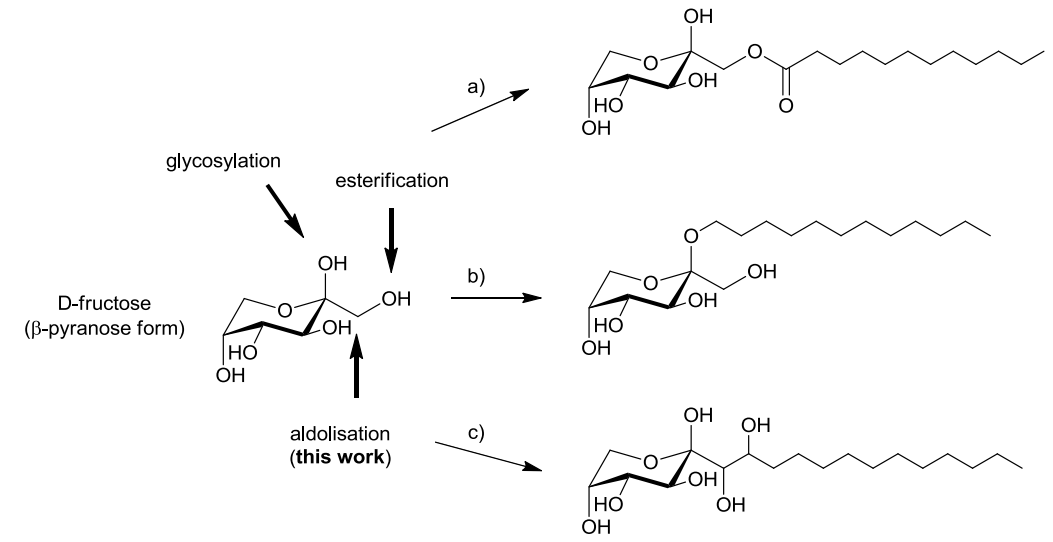


Scheme 1. Strategies for the alkylation of unprotected D-fructose (only one tautomer is represented for clarity). a) esterification with fatty acids; b) glycosylation with fatty alcohols; c) aldolization with fatty aldehydes.

Similarly, long alkyl chain derivatives such as decyl- and dodecylfructosides were obtained as a mixture of tautomers from the direct $\mathrm{BF}_{3^{-}}{ }^{40}$ or MCM-41-catalysed $^{41} \quad$ glycosylation of $\quad$ fructose. Alkyl 1-O- $\beta$-D-fructopyranosides can be obtained as single tautomers by treatment of fructose with alcohol in the presence of $\mathrm{FeCl}_{3}$ ( 3 equiv.). ${ }^{42}$ This methodology was further extended to the preparation of a cationic glycine betaine incorporating an octadecanyl $\beta$-D-fructopyranoside. ${ }^{43}$ The two aforementioned strategies, i.e. esterification and glycosylation, give access to $O$-acylated and $O$-alkylated fructose but cannot be used for C-alkylation. In this context, we describe herein a new approach for the alkylation of unprotected fructose by direct aldolization using a range of fatty aldehydes as alkylating agents to give C-C bond-linked surfactants (Scheme 1, c). The corresponding alkylated fructoses were also reduced under hydrogen pressure to give the corresponding alkylated heptaols.

\section{RESULTS AND DISCUSSION}

As a part of a research programme aiming at developing robust bio-based surfactants 
for eco-extraction or cosmetic applications, we have previously reported the preparation ether-linked sugar-based surfactants. ${ }^{44-47}$ Recently, we have been interested in developing $\mathrm{C}-\mathrm{C}$ bond linked surfactants. In this context, we have reported the base-catalysed aldolization of unprotected 1,3-dihydroxyacetone (DHA) towards the

formation of tetraol surfactants. ${ }^{48}$ Considering that fructose, under its acyclic keto-form, shares the same $\alpha$-hydroxyketone moiety than DHA, we envisioned that it could also be subjected to direct aldolization with aldehydes.

\section{Alkylation of fructose through aldolization}

To test this hypothesis, we have first investigated the base-catalysed aldolization of fructose 1 (5 equiv) in $1: 1 \mathrm{EtOH} / \mathrm{H}_{2} \mathrm{O}$ at $20^{\circ} \mathrm{C}$ using hydrocinnamaldehyde 2 ( 1 equiv) as a model substrate and $\mathrm{NMe}_{3}(0.5$ equiv. $)$ as a base. Unfortunately, only traces of the desired product could be detected even after 72 hours of reaction (Table 1, entry 1). These results were not surprising considering that fructose exists as a mixture of 4 cyclic tautomers in solution and the acyclic keto-form represents only $0.5-1 \%$ at $25^{\circ} \mathrm{C}^{3}$ In order to promote this open-chain form, the temperature was progressively increased from 20 to $100^{\circ} \mathrm{C}$ under microwave irradiation (Table 1, entries 2-5). Encouragingly, the aldolization product 3 was obtained with $31 \%$ yield at $60^{\circ} \mathrm{C}$ (Table 1, entry 3). However, higher temperatures did not improve the results probably due to the degradation of fructose under these conditions. The conversion and yield were then followed over time at $60^{\circ} \mathrm{C}$ under microwave irradiation (Figure 1). 
Table 1. Influence of the temperature and time on the aldolization of fructose. ${ }^{a}$

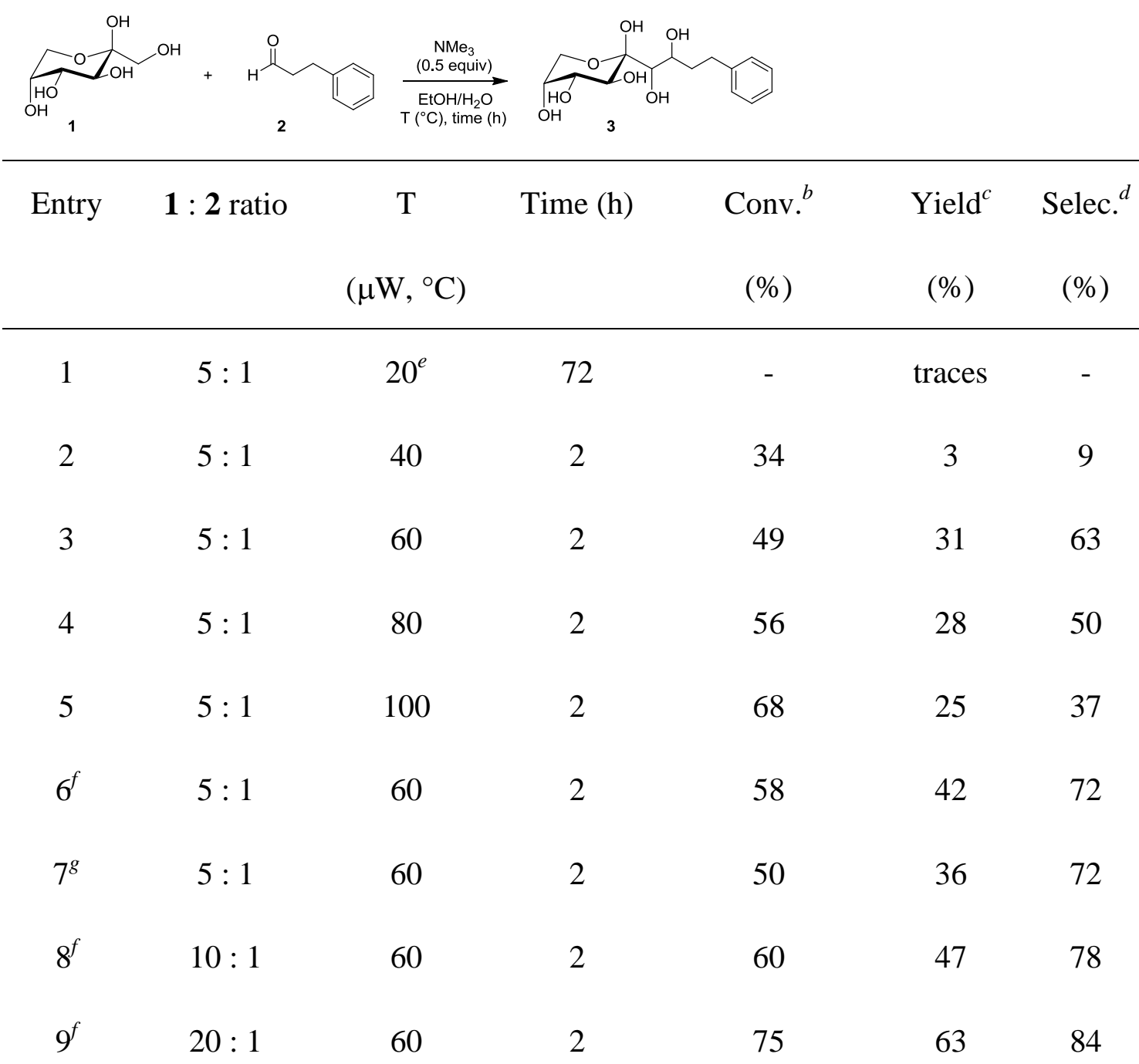

${ }^{a}$ Reaction conditions: sealed tube, fructose 1 ( $1 \mathrm{~g}, 5.6 \mathrm{mmol}, 5$ equiv.), aldehyde 2 (0.15 g, $1.1 \mathrm{mmol}, 0.28 \mathrm{M}), \mathrm{NMe}_{3}$ (0.5 equiv), $\mathrm{H}_{2} \mathrm{O} / \mathrm{EtOH}(\mathrm{v} / \mathrm{v} 1: 1,4 \mathrm{~mL}), \mathrm{T}(40-100$ $\left.{ }^{\circ} \mathrm{C}, \mu \mathrm{W}\right) .{ }^{b}$ Conversion of aldehyde 2 , determined by GC using calibration curves. ${ }^{c}$ Determined by GC using calibration curves after trimethylsilylation with HMDS/TMSCl. ${ }^{d}$ Selectivity was calculated as follow: $\mathrm{S}=$ yield / conversion. Reaction carried out without microwave under traditional heating. ${ }^{f}[2]=0.56 \mathrm{M},{ }^{g}[2]=$ $1.12 \mathrm{M}$.

The best results were obtained after 2 hours but a prolonged time was found deleterious 
for the yield while the conversion still progresses. This has been attributed to the degradation of the product through a retro-aldolization process, thus releasing the aldehyde that undergoes self-aldolization. Increasing the concentration of aldehyde $\mathbf{2}$ to $0.56 \mathrm{M}$ improved the yield to $42 \%$ but no further improvement was observed at higher concentration (Table 1, entries 6-7). Other parameters, such as the base loading and the proportions of the EtOH/ $\mathrm{H}_{2} \mathrm{O}$ system, were also screened but, once again, no improvement was obtained (Table S1 and S2). The fructose / aldehyde ratio was also switched from 5:1 to 1:5 using hydrocinnamaldehyde as a model substrate but the desired product 3 was only formed with $4 \%$ yield. In that case, the main byproduct, formed by self-aldolisation of hydrocinnamaldehyde, was isolated with $55 \%$ yield. Considering that the aldolization is a reversible process, the fructose/aldehyde ratio was progressively increased in order to shift the equilibrium towards the formation of the desired product (Table 1, entries 8-9). This is only reasonable due to the wide availability and low cost of fructose, provided that excess fructose could be recovered. Moreover, it is known, notably from the works of Breslow, ${ }^{49,50}$ Lubineau ${ }^{51,52}$ and Plusquellec, ${ }^{53-56}$ that highly concentrated solution of carbohydrates in water can enhance the kinetics of a reaction through hydrophobic effects. 


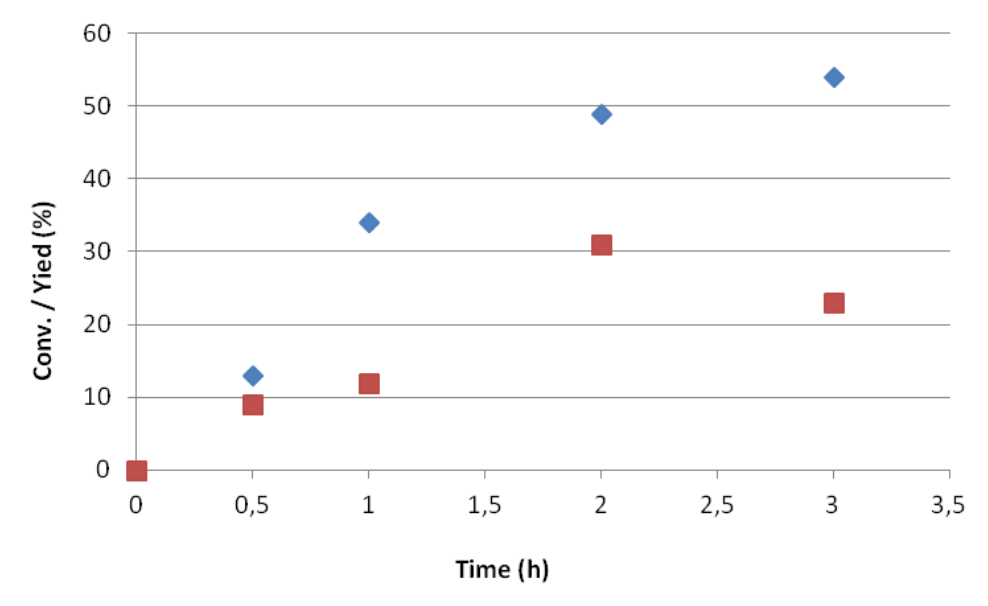

Figure 1. Conversion of aldehyde 2 ( $\%$, blue diamonds) and yield of aldolization product 3 (\%, red squares) over time. Conditions: $60^{\circ} \mathrm{C}$ under microwave irradiation. Therefore, when the reaction was carried out with 20 equivalents of fructose, i.e. about $2 \mathrm{~g} . \mathrm{mL}^{-1}$, the aldolization product 3 was obtained with $63 \%$ yield (Table 1, entry 9). It should be noted that, under these conditions, the solubility limit of fructose in the $\mathrm{EtOH} / \mathrm{H}_{2} \mathrm{O}$ system is reached at room temperature but the reaction mixture becomes homogeneous upon heating to $60^{\circ} \mathrm{C}$. Finally, increasing the reaction time did not improve the conversion of aldehyde $\mathbf{2}$, indicating that an equilibrium is probably reached. The scope of the aldolization of fructose was investigated with a range of aliphatic aldehydes with different chain lengths (Table 2). 
Table 2. Aldolization of fructose with a range of aldehydes. ${ }^{a}$

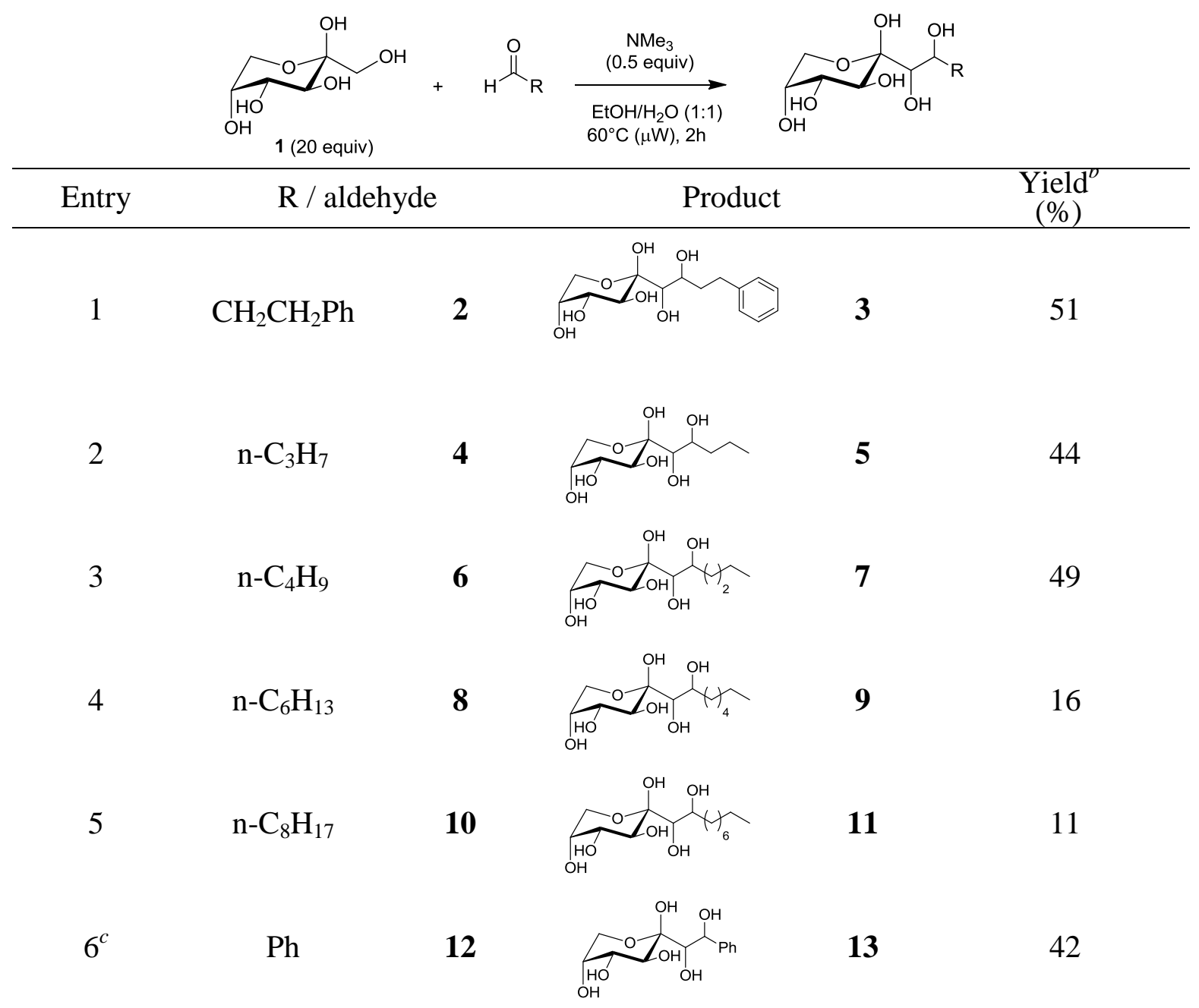

${ }^{a}$ Reaction conditions: sealed tube, fructose 1 (4 g, 22.2 mmol, 20 equiv.), aldehyde (1 equiv., $0.56 \mathrm{M}), \mathrm{NMe}_{3}$ (0.5 equiv), $\mathrm{H}_{2} \mathrm{O} / \mathrm{EtOH}(\mathrm{v} / \mathrm{v} 1: 1,2 \mathrm{~mL}), 60^{\circ} \mathrm{C}(\mu \mathrm{W}), 2$ hours. $^{b}$ Isolated yield after column chromatography. ${ }^{\mathrm{c}}$ Reaction time $=1$ hour. Only one tautomer is represented for clarity.

The reaction with hydrocinnamaldehyde 2 under the previously optimized conditions gave the aldolization product $\mathbf{3}$ with 51\% isolated yield after column chromatography (Table 2, entry 1). Similar results were obtained using butanal and pentanal as alkylating agents, and compounds 5 and 7 were isolated with 44 and $49 \%$ yield, respectively (Table 2, entries 2-3). Heptanal and nonanal were next considered as bio-based aldehydes in order to provide surfactants with $100 \%$ renewable content, that 
is, nowadays, a strong marketing argument. ${ }^{57}$ Indeed, these two aldehydes can be prepared from vegetable oil derivatives, more precisely from the cleavage of methyl ricinoleate ${ }^{58}$ or methyl oleate. ${ }^{59-63}$ Unfortunately, the alkylated fructose $\mathbf{9}$ and $\mathbf{1 1}$ were only obtained with 16 and $11 \%$ yield, respectively (Table 2, entries 4-5). Finally, benzaldehyde 12 was also used and the aldolisation product 13 was obtained with $42 \%$ yield, thus showing that the protocol is also applicable to aromatic aldehydes (Table 2, entry 6).

To further demonstrate the utility of this methodology, a scale-up reaction was performed using 40 times more reagents. Fructose and HCA 2 were dissolved in $40 \mathrm{~mL}$ of a EtOH/water mixture $(\mathrm{v} / \mathrm{v}, 1: 1)$ in a standard $250-\mathrm{mL}$ flask and $\mathrm{NMe}_{3}$ was added. The flask was placed in a 70-L microwave cavity (Milestone, FlexiWAVE®) and stirred at $60^{\circ} \mathrm{C}$ for 2 hours (the temperature was controlled thanks to an optic fiber sensor). Under these conditions, the aldolization product 3 was isolated with $48 \%$ yield (Scheme 2).

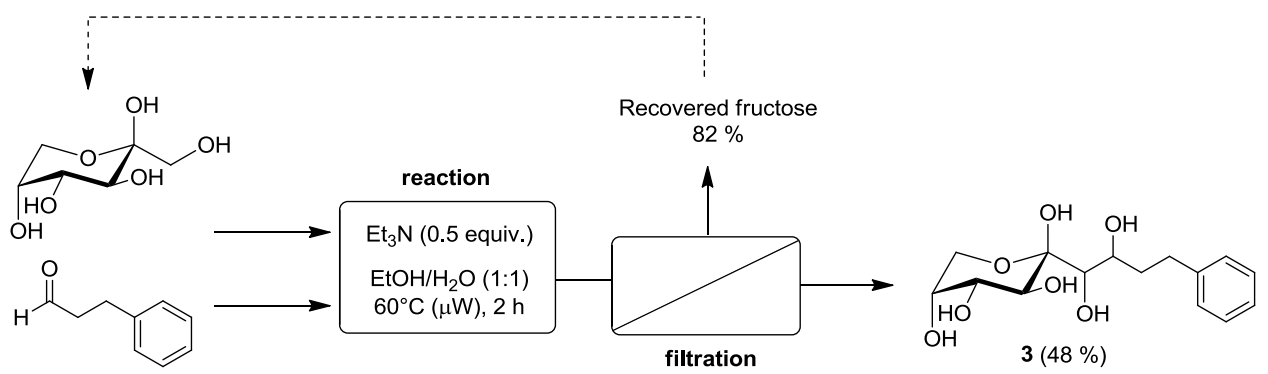

Scheme 2. Aldolization of fructose on a larger scale and recovery of excess fructose.

Excess fructose was also removed from the reaction mixture by cristallization and was recovered with $82 \%$ yield. This result indicates that even if there is some degradation or 
oligomerization of fructose, it should not represent a significant amount. To verify this, fructose was treated with $\mathrm{Me}_{3} \mathrm{~N}$ (or $\mathrm{K}_{2} \mathrm{CO}_{3}$, vide infra) under microwave irradiation for 2 hours but in the absence of the aldehyde. Satisfyingly, no reaction was observed and fructose was recovered unaltered, thus indicating that no degradation or oligomerization occur under these conditions. Overall, this method allows the direct alkylation of unprotected fructose through aldolization using aldehydes as alkylating agents. The main limitation is that only poor yields were obtained when using fatty aldehydes, which is unfortunate considering that surfactant applications are targeted. This has been attributed to the low solubility of fatty aldehydes in the EtOH/ $\mathrm{H}_{2} \mathrm{O} /$ sugar solvent system, as observed by the formation of a two-phase mixture. That is the reason why, we have re-investigated the reaction under phase transfer catalysis (Table 3). In that case, $\mathrm{NMe}_{3}$ was substituted by an inorganic base $\left(\mathrm{K}_{2} \mathrm{CO}_{3}\right)$ for solubility reasons. It is well soluble in water but poorly in fatty aldehydes, so it should prevent the self-aldolisation of aldehydes, leading to better yield and selectivity for the desired products. 
Table 3. Screening of phase transfer catalysts. ${ }^{a}$

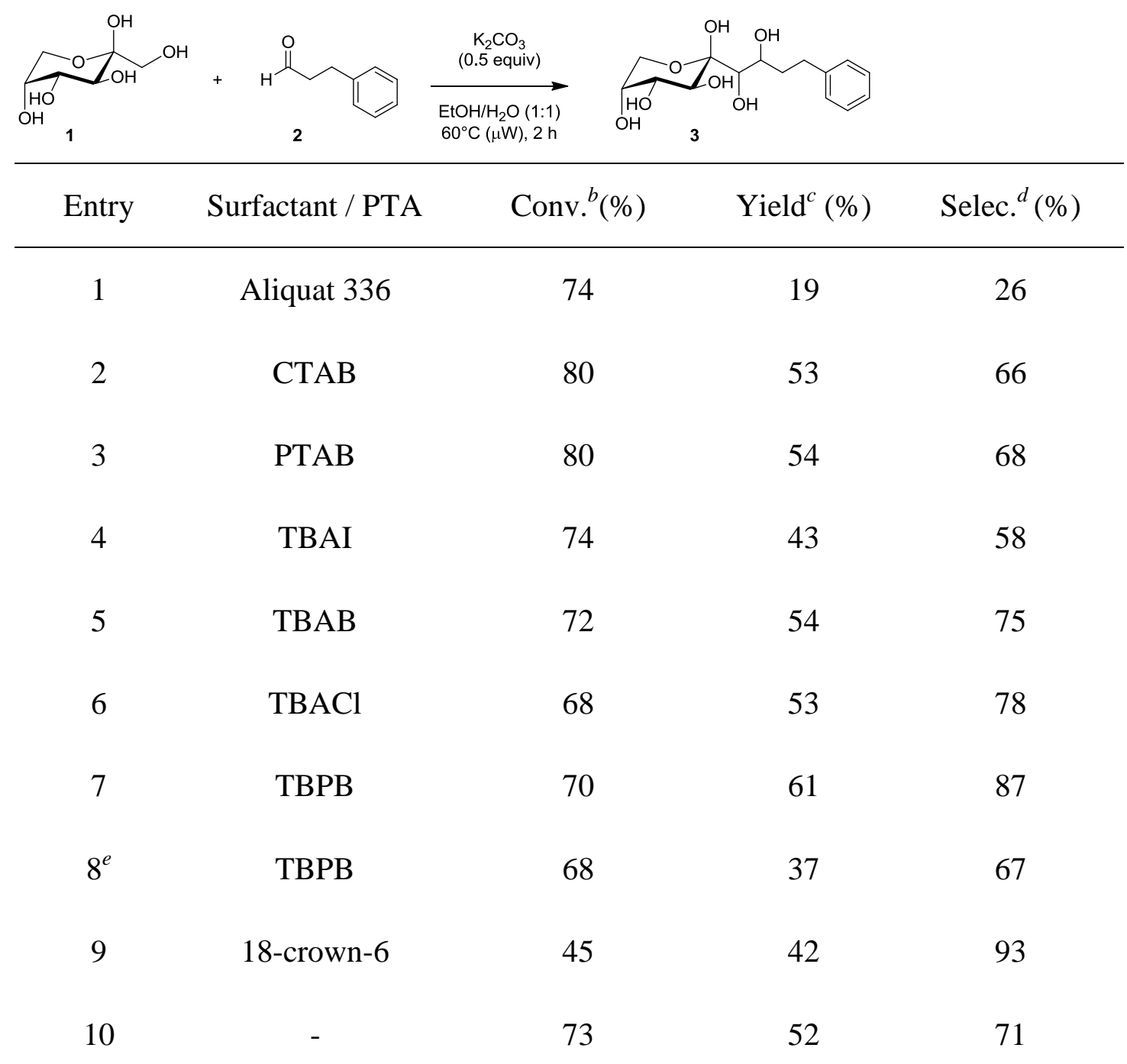

${ }^{a}$ Reaction conditions: sealed tube, fructose 1 (3 g, 16.7 mmol, 20 equiv.), aldehyde 2 (1 equiv., $0.56 \mathrm{M}), \mathrm{K}_{2} \mathrm{CO}_{3}(0.5$ equiv), surfactant or phase transfer agent (1 equiv.), $\mathrm{H}_{2} \mathrm{O} / \mathrm{EtOH}(\mathrm{v} / \mathrm{v} 1: 1,3 \mathrm{~mL}), 60^{\circ} \mathrm{C}(\mu \mathrm{W}), 2$ hours. ${ }^{b}$ Conversion of aldehyde 2 , determined by GC using calibration curves. ${ }^{c}$ Determined by GC using calibration curves after trimethylsilylation with HMDS/TMSCl. ${ }^{d}$ Selectivity was calculated as follow: $\mathrm{S}=$ yield $/$ conversion. ${ }^{e} 0.5$ equiv. of TBPB was used. Aliquat 336: methyltrioctyl(decyl)ammonium chloride, CTAB: cetyltrimethylammonium bromide, PTAB, phenyltrimethlammonium bromide, TBAI: tetrabutylammonium iodide, TBAB: tetrabutylammonium bromide, TBAC: tetrabutylammonium chloride, TBPB: tetrabutylphosphonium bromide. 
Aliquat 336 was first used but gave a poor yield (Table 3, entry 1). CTAB and PTAB gave improved results with about 53-54\% yield (Table 3, entries 2-3). Tetrabutylammonium salts (iodide, bromide, chloride) gave similar yields but the selectivity was improved to $78 \%$ using TBAC (Table 3, entries 4-6). Satisfyingly, tetrabutylphosphosphonium bromide (TBPB) gave $61 \%$ yield and a high $87 \%$ selectivity for the aldolization product 3 (Table 3, entry 7). Note that only $37 \%$ yield could be obtained when using only 0.5 equiv. of TBPB (Table 3 , entry 8). The replacement of phase transfer catalysts by a potassium-selective sequestering agent such as 18 -crown- 6 gave an excellent $93 \%$ selectivity but the yield plateaued at $42 \%$ (Table 3, entry 9). Finally, a blank experiment without any phase transfer agent was also carried out (Table 3, entry 10). In that case, only $52 \%$ yield of $\mathbf{3}$ and $71 \%$ selectivity were obtained, thus indicating the important role of the phosphonium bromide in this protocol.

The nature of the inorganic base was next probed using TBPB (Table 4). 
Table 4. Screening of inorganic bases. ${ }^{a}$

\begin{tabular}{ccccc}
$\mathrm{O}_{\mathrm{OH}}$ \\
\hline 1
\end{tabular}

${ }^{a}$ Reaction conditions: sealed tube, fructose 1 (3 g, 16.7 mmol, 20 equiv.), aldehyde 2 (1 equiv., $0.56 \mathrm{M}), \mathrm{K}_{2} \mathrm{CO}_{3}$ (0.5 equiv), surfactant or phase transfer agent (1 equiv.), $\mathrm{H}_{2} \mathrm{O} / \mathrm{EtOH}(\mathrm{v} / \mathrm{v} 1: 1,3 \mathrm{~mL}), 60^{\circ} \mathrm{C}(\mu \mathrm{W}), 2$ hours. ${ }^{b}$ Conversion of aldehyde 2 , determined by GC using calibration curves. ${ }^{c}$ Determined by GC using calibration curves after trimethylsilylation with HMDS/TMSCl. ${ }^{d}$ Selectivity was calculated as follow: $\mathrm{S}=$ yield $/$ conversion. $^{e} 1$ equiv. of $\mathrm{K}_{2} \mathrm{CO}_{3}$ was used.

Using a range of carbonates, the best yield and selectivity were achieved using $\mathrm{K}_{2} \mathrm{CO}_{3}$ (Table 4, entries 1-4). Consequently, other potassium bases were 
investigated. $\mathrm{KHCO}_{3}$ also promotes the reaction with similar selectivity than $\mathrm{K}_{2} \mathrm{CO}_{3}$ but was found to be slightly less active (Table 4 , entry 5). This result probably explains why only 0.5 equiv. of $\mathrm{K}_{2} \mathrm{CO}_{3}$ can be used in the reaction. Other bases such as $\mathrm{KOH}, \mathrm{KOAc}$ and $\mathrm{KO}^{t} \mathrm{Bu}$ gave lower selectivities due to their ability to promote the competitive self-aldolization of the aldehyde (Table 4, entries 6-8). Increasing the quantity of $\mathrm{K}_{2} \mathrm{CO}_{3}$ to 1 equivalent did not improve the results (Table 4, entry 9). Finally, a blank experiment was carried out in the absence of the base. Predictably, no desired product $\mathbf{3}$ was detected under these conditions, indicating the essential role of the base in this process (Table 4, entry $10)$.

The nature of the organic co-solvent was also studied as a (v/v) 1:1 ratio with water (Table 5). Among alcoholic solvents tested, only EtOH gave satisfactory results (Table 5, entries 1-4). Ethereal solvents such as THF, 2-MeTHF and CPME were also screened but none of them was able to efficiently promote the reaction (Table 5, entries 5-7). The reaction almost did not occur in toluene, indicating that the conditions developed are quite different from the conventional phase transfer catalysis (Table 5, entry 8). Finally, the presence of a co-solvent was found essential as the reaction in pure water only gave $8 \%$ of the desired product and led to self-aldolization of aldehyde 2 (Table 5, entry 9). 
Table 5. Screening of organic solvents. ${ }^{a}$

\begin{tabular}{|c|c|c|c|c|}
\hline Entry & Co-Solvent & Conv. $^{b}(\%)$ & $\operatorname{Yield}^{c}(\%)$ & Selec. $^{d}(\%)$ \\
\hline 1 & $\mathrm{MeOH}$ & 62 & 42 & 68 \\
\hline 2 & EtOH & 70 & 61 & 87 \\
\hline 3 & $\mathrm{BuOH}$ & 83 & 5 & 6 \\
\hline 4 & ${ }^{i} \mathrm{PrOH}$ & 64 & 31 & 48 \\
\hline 5 & THF & 42 & 23 & 55 \\
\hline 6 & 2-MeTHF & 21 & 16 & 76 \\
\hline 7 & CPME & 47 & 8 & 17 \\
\hline 8 & Toluene & 7 & 2 & 29 \\
\hline 9 & - & 77 & 8 & 10 \\
\hline
\end{tabular}

${ }^{a}$ Reaction conditions: sealed tube, fructose 1 (3 g, 16.7 mmol, 20 equiv.), aldehyde 2 (1 equiv., $0.56 \mathrm{M}), \mathrm{K}_{2} \mathrm{CO}_{3}$ (0.5 equiv), surfactant or phase transfer agent (1 equiv.), Solvent/ $\mathrm{H}_{2} \mathrm{O}(\mathrm{v} / \mathrm{v} 1: 1,3 \mathrm{~mL}), 60^{\circ} \mathrm{C}(\mu \mathrm{W}), 2$ hours. ${ }^{b}$ Conversion of aldehyde 2 , determined by GC using calibration curves. ${ }^{c}$ Determined by GC using calibration curves after trimethylsilylation with HMDS/TMSCl. ${ }^{d}$ Selectivity was calculated as follow: $\mathrm{S}=$ yield / conversion.

The scope of the aldolization of fructose has been re-investigated in the presence of fatty aldehydes under the optimized conditions (Table 6). 
Table 6. Aldolization of fructose with fatty aldehydes. ${ }^{a}$

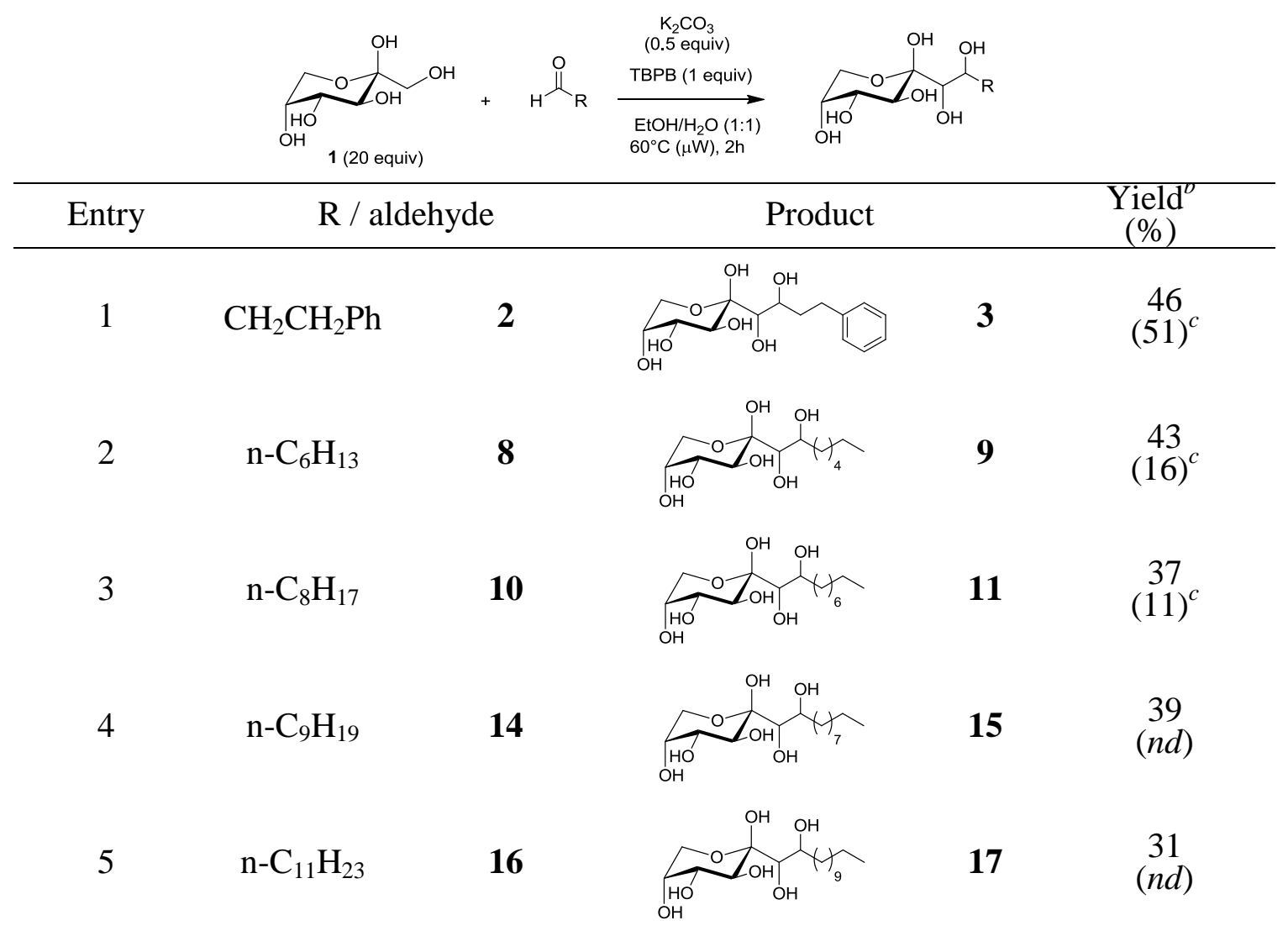

${ }^{a}$ Reaction conditions: sealed tube, fructose 1 (4 g, 22.2 mmol, 20 equiv.), aldehyde (1 equiv., $0.56 \mathrm{M}), \mathrm{K}_{2} \mathrm{CO}_{3}$ (0.5 equiv), TBPB (1 equiv.), $\mathrm{H}_{2} \mathrm{O} / \mathrm{EtOH}\left(\mathrm{v} / \mathrm{v} 1: 1,2 \mathrm{~mL}\right.$ ), $60^{\circ} \mathrm{C}$ $(\mu \mathrm{W}), 2$ hours. ${ }^{b}$ Isolated yield after column chromatography. ${ }^{c}$ Yields in brakets were previously obtained with $\mathrm{NMe}_{3}$, see Table 2. Only one tautomer is represented for clarity. nd: not determined.

The results were compared with those previously obtained with $\mathrm{NMe}_{3}$. With hydrocinnamaldehyde $\mathbf{2}$, the yield obtained was roughly the same, around $50 \%$, whatever the conditions (Table 6, entry 1 ). However, when using heptanal and nonanal, the yield of the aldolization products $\mathbf{9}$ and $\mathbf{1 1}$ were significantly improved to 43 and 37\%, respectively (Table 6, entries 2-3). Decanal and dodecanal can be also used and the corresponding alkylated fructose $\mathbf{1 5}$ and $\mathbf{1 7}$ were obtained with 39 and $31 \%$ yield, respectively (Table 6, entries 4-5). These 
isolated yields remain modest but they are satisfactory given the difficulty to react highly polar unprotected fructose with hydrophobic aldehydes. For comparison, the reaction of decanol and dodecanol with unprotected fructose led to the corresponding decyl and dodecyl fructosides with 33 and $35 \%$ isolated yields. $^{42}$

\section{Mechanism proposal}

The following mechanism is proposed to rationalize the conditions developed so far (Scheme 3). Indeed, these reaction conditions are not trivial but they allow an original alkylation mode of unprotected fructose through aldolization. At the beginning of the reaction, fructose and $\mathrm{K}_{2} \mathrm{CO}_{3}$ are totally miscible at $60^{\circ} \mathrm{C}$ in the $\mathrm{EtOH} /$ water solvent system that is making only one phase. The fatty aldehydes and TBPB are standing on top of this EtOH/water phase. First, a large excess of fructose $\mathbf{I}$ is necessary to favour the open-chain form II that presenting less than $1 \%$ in solution. This $\alpha$-hydroxyketone could be deprotonated, similarly than dihydroxyacetone, with a weak base such as $\mathrm{K}_{2} \mathrm{CO}_{3}$ to give the corresponding potassium enolate III. This intermediate could undergo ion metathesis with the phosphonium bromide to generate the phosphonium enolate IV along with one equivalent of $\mathrm{KBr}$. Alternatively, the ion metathesis could first occur between $\mathrm{K}_{2} \mathrm{CO}_{3}$ and the phosphonium bromide to generate $\mathrm{PBu}_{4}{ }^{+} \cdot \mathrm{HCO}_{3}{ }^{-}$or $\left(\mathrm{PBu}_{4}{ }^{+}\right)_{2} \cdot \mathrm{CO}_{3}{ }^{2-}$ species, that could deprotonate fructose to give the same intermediate IV. Therefore, the nucleophilicity of this species is enhanced and it could react with the hydrophobic aldehyde, giving phosphonium alcoholate $\mathbf{V}$. 
Protonation of $\mathbf{V}$ should generate aldolization product VI that spontaneously cyclized to give a mixture of tautomers. The GC chromatogram after derivatization by trimethylsilylation using $\mathrm{HMDS} / \mathrm{TMSCl}$ gave a mixture of 3 isomers. By analogy with fructose and other works on fructose esters, we have identified the $\beta$-pyranoid form VII as the main tautomers and the presence of the $\alpha$ - and $\beta$-furanoid forms IX and $\mathbf{X}$. The $\alpha$-pyranoid form VIII was not detected as this species is usually very minor in solution. ${ }^{3}$ Considering the facts that fructose is chiral and exists as a mixture of 3 main tautomers, this indicates that the key aldolization step is highly diastereoselective. This is in accordance with the high diastereomeric ratio (up to 96:4 d.r.) obtained in our previous work on the aldolization of DHA. ${ }^{48}$ In this sytem, the crucial role of EtOH is difficult to rationalize, however, we hypothesized that it could play the role of a hydrotrope ${ }^{64,65}$ i.e., it could enhance the solubility of the hydrophobic aldehyde in water. When less polar and less water-soluble solvents were used (see Table 5), the self-aldolization product XI was mainly formed. 


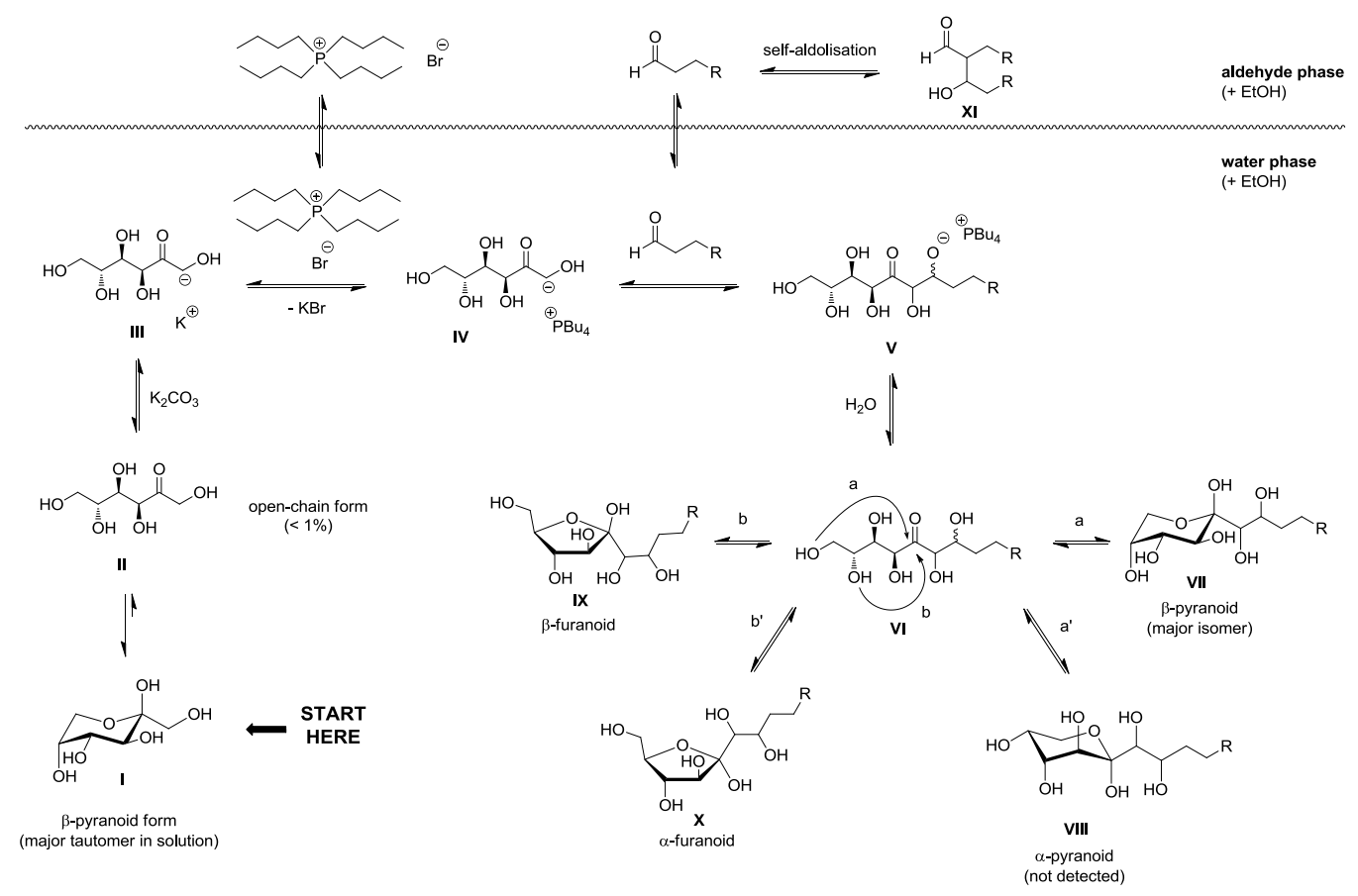

Scheme 3. Mechanism proposal

\section{Reduction of aldolization products to heptaols}

The reduction of the fructose aldolization products was carried out in order to extend the scope of the new compounds that could be used as non ionic surfactants (Table 7). The aldolization product 3 was first reduced under hydrogen (40 bar) at $100^{\circ} \mathrm{C}$ in water (Table 7 , entry 1$)$. Under these conditions, both the carbonyl group and the phenyl ring are completely reduced, thus giving heptaol 18 with $94 \%$ yield. Similarly, compound 13, bearing a phenyl group, was completely reduced to the corresponding heptaol 19 with $96 \%$ yield (Table 7 , entry 2). Milder conditions (e.g., lower hydrogen pressure or lower temperature) were also used to preserve the phenyl ring integrity but led to a complex mixture of products (partial reduction of the phenyl ring and/or the fructose moiety). The other aldolization products were hydrogenated under the same conditions to give 
the corresponding heptaols 19-25 with 84-95 yield (Table 7, entries 3-8). These reduced species could be particularly interesting as they could not cyclize in solution. 
Table 7. Reduction of the fructose aldolization products. ${ }^{a}$

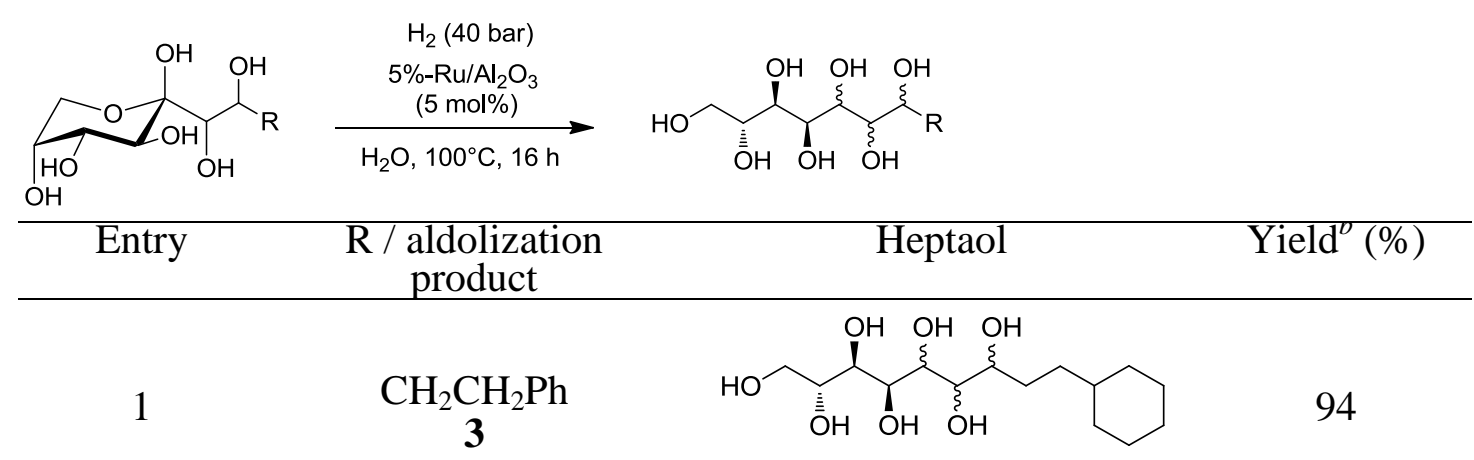

18

2

$\mathrm{Ph}$<smiles>OC[C@@H](O)C(O)C(O)[C@H](O)[C@H](O)C1CCCCC1</smiles>

96

19

3

$\mathrm{n}-\mathrm{C}_{3} \mathrm{H}_{7}$
$\mathbf{5}$<smiles>CCCC(O)C(O)C(O)C(O)C(O)CO</smiles>

20

4

$\mathrm{n}-\mathrm{C}_{4} \mathrm{H}_{9}$
7<smiles>CCCC[C@H](O)[C@H](O)[C@H](O)[C@H](O)[C@H](O)[C@H](O)CO</smiles>

95

21

5

$\underset{\mathbf{9}}{\mathrm{n}-\mathrm{C}_{6} \mathrm{H}_{13}}$<smiles>CCC(C)C(O)C(O)C(O)C(O)C(O)C(O)CO</smiles>

86

22

6

$\underset{\mathbf{1 1}}{\mathrm{n}-\mathrm{C}_{8} \mathrm{H}_{17}}$<smiles>CCC(C)C(O)C(O)C(O)C(O)C(O)C(O)CO</smiles>

23

7

$\underset{\mathbf{1 5}}{\mathrm{n}-\mathrm{C}_{9} \mathrm{H}_{19}}$<smiles>[Y][C@H](O)[C@H](O)[C@H](O)[C@H](O)[C@H](O)[C@H](O)[C@H](O)CO</smiles>

84

24

8

$\underset{\mathbf{1 7}}{\mathrm{n}-\mathrm{C}_{11} \mathrm{H}_{23}}$<smiles>CC[C@H](O)[C@H](O)[C@H](O)[C@H](O)[C@H](O)[C@H](O)[C@H](O)CO</smiles>

87

25

${ }^{a}$ Reaction conditions: 30-mL stainless steel autoclave, aldol (200 mg), hydrogen pressure (40 bar), $5 \%-\mathrm{Ru} / \mathrm{Al}_{2} \mathrm{O}_{3}(5 \mathrm{~mol} \%), \mathrm{H}_{2} \mathrm{O}(6 \mathrm{~mL}), 100^{\circ} \mathrm{C}, 16$ hours. ${ }^{b}$ Isolated yield. 


\section{CONCLUSIONS}

In conclusion, we have developed a new alkylation mode of unprotected fructose by direct aldolization using fatty aldehydes as alkylating agents. The reaction occurs in benign solvents $\left(1: 1\right.$ mixture of $\mathrm{EtOH} /$ water) at $60^{\circ} \mathrm{C}$ under microwave irradiation. Under these conditions, the corresponding alkylated fructoses were isolated with $31-46 \%$ yields, that is satisfactory given the difficulty to react highly polar fructose with hydrophobic aldehydes. Advantageously, surfactants with $100 \%$ renewable content can be produced through this methodology, notably, when using vegetable oil derived heptanal and nonanal. The aldolization products were also reduced under hydrogen to give the corresponding alkylated heptaols with $84-96 \%$ isolated yields. Further studies will focus upon studying in details the physico-chemical properties of all these new amphiphilic species.

\section{EXPERIMENTAL}

\section{General information}

All reagents were used as received from the chemical companies. D-Fructose (>99 \% purity) was purchased from sigma-Aldrich. Hydrocinamaldehyde, butanal, pentanal, hexanal, heptanal, nonanal, decanal and dodecanal and were supplied by Sigma-Aldrich or Alfa-Aesar, and were purified by distillation before use (except dodecanal). $\mathrm{Ru} / \mathrm{Al}_{2} \mathrm{O}_{3}(5 \%)$ was purchased from Strem Chemicals.

\section{General procedure for the aldolization of D-fructose.}


Method A (organic base)

In a sealed tube, D-fructose 1 (4.00 g, $22.2 \mathrm{mmol}, 20$ equiv.) was dissolved in a 1:1 mixture of EtOH $(1 \mathrm{~mL})$ and water $(1 \mathrm{~mL})$. Then, trimethylamine $(0.13 \mathrm{~mL}, 0.56 \mathrm{mmol}$, 0.5 equiv.) and the aldehyde ( 1 equiv.) were added into the solution. The reaction mixture was heated at $60^{\circ} \mathrm{C}$ for 2 hours under microwave irradiation. After reaction, the solvent was removed in vacuum, and the residue was purified by column chromatography $\left(\mathrm{CH}_{2} \mathrm{Cl}_{2} / \mathrm{MeOH} 15: 1 \rightarrow 12: 1\right)$ to give aldolization products. All details of the chemical characterizations $\left({ }^{1} \mathrm{H}\right.$ NMR, ${ }^{13} \mathrm{C}$ NMR, MS $)$ are given in the ESI.

Method B (inorganic base)

In a sealed tube, D-fructose 1 (4.00 g, $22.2 \mathrm{mmol}, 20$ equiv.) and $\mathrm{K}_{2} \mathrm{CO}_{3}$ (77 mg, 0.56 mmol, 0.5 equiv.) were dissolved in a 1:1 mixture of EtOH $(2 \mathrm{~mL})$ and water $(2 \mathrm{~mL})$. The aldehyde (1 equiv.) and tetrabutylphosphonium bromide (TBPB, $377 \mathrm{mg}, 1.11$ mmol, 1 equiv.) were added to give an organic phase on top of the water phase. The reaction mixture was heated at $60^{\circ} \mathrm{C}$ for 2 hours under microwave irradiation. After reaction, the solvent was removed in vacuum, and the residue was purified by column chromatography $\left(\mathrm{CH}_{2} \mathrm{Cl}_{2} / \mathrm{MeOH} 15: 1 \rightarrow 12: 1\right)$ to give aldolization products. All details of the chemical characterizations $\left({ }^{1} \mathrm{H}\right.$ NMR, ${ }^{13} \mathrm{C}$ NMR, MS $)$ are given in the ESI.

\section{General procedure for the hydrogenation of aldolization products to heptaols.}

In a $30-\mathrm{mL}$ stainless steel autoclave, the aldolization products (200 $\mathrm{mg}, 1$ equiv.) were dissolved in water $(6 \mathrm{~mL})$ and $5 \%-\mathrm{Ru} / \mathrm{Al}_{2} \mathrm{O}_{3}(5 \mathrm{~mol} \%$ in $\mathrm{Ru})$ was added. The autoclave was flushed with hydrogen (10 bar) for 3 times. The solution was stirred (600 rpm) under 40 bar hydrogen at $100^{\circ} \mathrm{C}$ for 16 hours. After cooling to room temperature, the 
reaction mixture was filtered (Milllipore Durapore filter $0.01 \mu \mathrm{m}$ ) and washed with EtOH. The filtrate was concentrated under vacuum to give heptaol products 16-21. All details of the chemical characterizations $\left({ }^{1} \mathrm{H}\right.$ NMR, ${ }^{13} \mathrm{C}$ NMR, MS $)$ are given in the ESI.

\section{ASSOCIATED CONTENT}

Supporting Information. The supporting information contains the general procedures, the characterization data of fructose aldolization products and heptaols, as well as ${ }^{1} \mathrm{H}$ and ${ }^{13} \mathrm{C}$ NMR spectra of all compounds.

\section{AUTHOR INFORMATION}

\section{Corresponding Authors}

*E-mail: nicolas.duguet@univ-lyon1.fr

* E-mail: marc.lemaire.chimie@univ-lyon1.fr

ORCID

Nicolas Duguet: 0000-0002-9425-7450

Marc Lemaire: 0000-0003-2800-0590

\section{Notes}

The authors declare no competing financial interest.

\section{ACKNOWLEDGEMENTS}


The China Scholarship Council (CSC) is warmly thanked for a Ph.D. grant to Biwen Zhu. Diego Carnaroglio (Milestone) and Olivier Leclercq (Equilabo) are also thanked for the demonstration of the FlexiWAVE®.

\section{REFERENCES}

1 Sheldon, R. A. Green and sustainable manufacture of chemicals from biomass: state of the art. Green Chem. 2014, 16, 950-963.

2 Besson, M.; Gallezot, P.; Pinel, C. Conversion of biomass into chemicals over metal catalysts. Chem. Rev. 2014, 114, 1827-1870.

3 Gallezot, P. Conversion of biomass to selected chemical products. Chem. Soc. Rev. 2012, 41, 1538-1558.

4 Corma, A.; Iborra, S.; Velty, A. Chemical routes for the transformation of biomass into chemicals. Chem. Rev. 2007, 107, 2411-2502.

5 Chatterjee, C.; Pong, F.; Sen, A. Chemical conversion pathways for carbohydrates. Green Chem. 2015, 17, 40-71.

6 Climent, M. J.; Corma, A.; Iborra, S. Converting carbohydrates to bulk chemicals and fine chemicals over heterogeneous catalysts. Green Chem. 2011, $13,520-540$.

7 Lichtenthaler, F. W. Towards improving the utility of ketoses as organic raw materials. Carbohydr. Res. 1998, 313, 69-89. 
8 Ricca, E.; Calabro, V.; Curcio, S.; Iorio, G. The state of the art in the production of gructose from inulin enzymatic hydrolysis. Crit. Rev. Biotechnol. 2007, 27, 129-145.

9 Yoo, C. G.; Li, N.; Swannell, M.; Pan, X. Isomerization of glucose to fructose catalyzed by lithium bromide in water. Green Chem. 2017, 19, 4402-4411.

10 Liu, C.; Carraher, J. M.; Swedberg, J. L.; Herndon, C. R.; Fleitman, C. N.; Tessonnier, J.-P. Selective base-catalyzed isomerization of glucose to fructose. ACS Catal. 2014, 4, 4295-4298.

11 Li, H.; Yang, S.; Saravanamurugan, S.; Riisager, A. Glucose isomerization by enzymes and chemo-catalysts: status and current advances. ACS Catal. 2017, 7, 3010-3029.

12 Delidovich, I.; Palkovits, R. Catalytic isomerization of biomass-derived aldoses: a review. ChemSusChem 2016, 9, 547-561.

13 Lobry de Bruyn, C. A.; Van Ekenstein, W. A. Action des alcalis sur les sucres, II. Transformation réciproque des uns dans les autres des sucres glucose, fructose et mannose. Recl. Trav. Chim. Pays-Bas. 1895, 14, 203-216.

14 White, J. S. Sucrose, HFCS, and Fructose: History, Manufacture, Composition, Applications, and Production. In: Rippe, J. (eds) Fructose, High Fructose Corn Syrup, Sucrose and Health. Nutrition and Health. Humana Press, New York, NY, 2014. 
15 Hill, A.; Tian, F.; Karboune, S. Synthesis of levan and fructooligosaccharides by levansucrase: catalytic, structural and substrate-specificity properties. Curr. Org. Chem. 2017, 21, 149-161.

16Dominguez, A. L.; Rodrigues, L. R.; Lima, N. M.; Teixeira, J. A. An overview of the recent developments on fructooligosaccharide production and applications. Food and Bioprocess Technol. 2014, 7, 324-337.

17 Van Putten, R.-J.; Van der Waal, J. C.; De Jong, E.; Rasrendra, C. B.; Heeres, H. J.; De Vries, J. G. Hydroxymethylfurfural, a versatile platform chemical made from renewable resources. Chem. Rev. 2013, 113, 1499-1597.

18 Rosatella, A. A.; Simeonov, S. P.; Frade, R. F. M.; Afonso, C. A. M. 5-Hydroxymethylfurfural (HMF) as a building block platform: Biological properties, synthesis and synthetic applications. Green Chem. 2011, 13, 754-793.

19 Karinen, R.; Vilonen, K.; Niemelae, M. Biorefining: heterogeneously catalyzed reactions of carbohydrates for the production of furfural and hydroxymethylfurfural. ChemSusChem 2011, 4, 1002-1016.

20 Wang, T.; Nolte, M. W.; Shanks, B. H. Catalytic dehydration of $\mathrm{C}_{6}$ carbohydrates for the production of hydroxymethylfurfural (HMF) as a versatile platform chemical. Green Chem. 2014, 16, 548-572.

21Zhang, Z.; Deng, K. Recent advances in the catalytic synthesis of 2,5-furandicarboxylic acid and its derivatives. ACS Catal. 2015, 5, 6529-6544. 
22 Gandini, A.; Lacerda, T. M.; Carvalho, A. J. F.; Trovatti, E. Progress of polymers from renewable resources: furans, vegetable oils, and polysaccharides. Chem. Rev. 2016, 116, 1637-1669.

23 Galbis, J. A.; García-Martín, M. de G.; De Paz, M. V.; Galbis, E. Synthetic polymers from sugar-based monomers. Chem. Rev. 2016, 116, 1600-1636.

24 Sousa, A. F.; Vilela, C.; Fonseca, A. C.; Matos, M.; Freire, C. S. R.; Gruter, G.-J. M.; Coelho, J. F. J.; Silvestre, A. J. D. Biobased polyesters and other polymers from 2,5-furandicarboxylic acid: a tribute to furan excellency. Polym. Chem. 2015, 6, 5961-5983.

25 Foley, P.; Kermanshahi pour, A.; Beach, E. S.; Zimmerman, J. B. Derivation and synthesis of renewable surfactants. Chem. Soc. Rev. 2012, 41, 1499-1518.

26 Hill, K. in Surfactants from Renewable Resources; ed. Kjellin, M., Johansson, I., Eds.; John Wiley \& Sons, Ltd., 2010.

27 Coulon, D.; Girardin, M.; Ghoul, M. Enzymic synthesis of fructose monooleate in a reduced pressure pilot scale reactor using various acyl donors. Process Biochem. 1999, 34, 913-918.

28 Rakmi, A. R.; Herawan, T. Properties of biosurfactant enzymatically prepared from productose and palm fatty acid. J. Oil Palm Res. 2000, 12, 117-122.

29 Şekeroğlu, G.; Fadıloğlu, S.; İbanoğlu, E. Production and characterisation of enzymatically produced lauric acid esters of fructose. J. Sci. Food Agric. 2002, $82,1516-1522$. 
30 Soultani, S.; Ognier, S.; Engasser, J.-M.; Ghoul, M. Comparative study of some surface active properties of fructose esters and commercial sucrose esters. Colloids Surf. A. 2003, 227, 35-44.

31 Šabeder, S.; Habulin, M.; Knez, Ž. Lipase-catalyzed synthesis of fatty acid fructose esters. J. Food Eng. 2006, 77, 880-886.

32 Ha, S. H.; Hiep, N. M.; Koo, Y.-M. Enhanced production of fructose palmitate by lipase-catalyzed esterification in ionic liquids. Biotechnol. Bioprocess Eng. 2010, 15, 126-130.

33 Ye, R.; Hayes, D. G. Optimization of the solvent-free lipase-catalyzed synthesis of fructose-oleic acid ester through programming of water removal. $J$. Am. Oil Chem. Soc. 2011, 88, 1351-1359.

34 Pomchini, L.; Richards, G. N. Thermolysis of sucrose in dimethyl sulphoxide solution. Carbohydr. Res. 1980, 87, 209-217.

35 Moody, W.; Richards, G. N. Thermolysis of sucrose in the presence of alcohols. A novel method for the synthesis of D-fructofuranosides. Carbohydr. Res. 1981, 97, 247-255.

36 Moody, W.; Richards, G. N. Formation and equilibration of D-fructosides and 2-thio- D-fructosides in acidified dimethyl sulfoxide: synthetic and mechanistic aspects. Carbohydr. Res. 1983, 124, 201-213.

37 Straathof, A. J. J.; Vrijenhoef, J. P.; Sprangers, E. P. A. T.; Van Bekkum, H.; Kieboom, A. P. G. Enzymic formation of $\beta$-D-fructofuranosides from sucrose: 
activity and selectivity of inventase in mixtures of water and alcohol. $J$. Carbohydr. Chem. 1988, 7, 223-238.

38De Goede, A. T. J. W.; Van Rantwijk, F.; Van Bekkum, H. Synthesis of alkyl fructosides. Starch/Staerke. 1995, 47, 233-237.

39 Verhart, C. G. J.; Fransen, C. T. M.; Zwanenburg, B.; Chittenden, G. J. F. Reaction of D-fructose, D-glucose and inulin with alcohols in the presence of iodine; a novel glycosidation procedure. Recl. Trav. Chim. Pays-Bas. 1996, 115, 133-139.

40Regeling, H.; Zwanenburg, B.; Chittenden, G. J. F. Decyl and dodecyl B-D-fructofuranosides. Carbohydr. Res. 1998, 314, 267-272.

41 Van der Heijden, A. M.; Van Rantwijk, F.; Van Bekkum, H. MCM-41 materials as catalysts for the synthesis of alkyl fructosides. J. Carbohydr. Chem. 1999, 18, 131-147.

42Ferrières, V.; Benvegnu, T.; Lefeuvre, M.; Plusquellec, D.; Mackenzie, G.; Watson, M. J.; Haley, J. A.; Goodby, J. W.; Pindak, R.; Durbin, M. K. Diastereospecific synthesis and amphiphilic properties of new alkyl $\beta$-D-fructopyranosides. J. Chem. Soc. Perkin Trans. 2. 1999, 951-959.

43 Goursaud, F.; Benvegnu, T. Synthesis of 1-octadecyl 5-betainylamino-5-deoxy- $\beta$-D-fructopyranoside hydrochloride as a new long-chain cationic sugar-based surfactant. Carbohydr. Res. 2009, 344, 136-139. 
44 Gozlan, C.; Lafon, R.; Duguet, N.; Redl, A.; Lemaire, M. Catalytic reductive cleavage of methyl $\alpha$-D-glucoside acetals to ethers using hydrogen as a clean reductant. $R S C A d v$. 2014, 4, 50653-50661.

45 Gozlan, C.; Deruer, E.; Duclos, M.-C.; Molinier, V.; Aubry, J.-M.; Redl, A.; Duguet, N.; Lemaire, M. Preparation of amphiphilic sorbitan monoethers through hydrogenolysis of sorbitan acetals and evaluation as bio-based surfactants. Green Chem. 2016, 18, 1994-2004.

46 Belmessieri, D.; Gozlan, C.; Duclos, M.-C.; Molinier, V.; Aubry, J.-M.; Dumitrescu, O.; Lina, G.; Redl, A.; Duguet, N.; Lemaire, M. Synthesis, surfactant properties and antimicrobial activities of methyl glycopyranoside ethers. Eur. J. Med. Chem. 2017, 128, 98-106.

47 Belmessieri, D.; Gozlan, C.; Duclos, M.-C.; Dumitrescu, O.; Lina, G.; Redl, A.; Duguet, N.; Lemaire, M. Dodecyl sorbitan ethers as antimicrobials against Gram-positive bacteria. Bioorg. Med. Chem. Lett. 2017, 27, 4660-4663.

48Zhu, B.; Belmessieri, D.; Ontiveros, J. F.; Aubry, J.-M.; Chen, G.-R.; Duguet, N.; Lemaire, M. Trialkylamine-catalyzed aldolization of unprotected 1,3-dihydroxyacetone (DHA) toward C-C bond-linked tetraol surfactants. $A C S$ Sustainable Chem. Eng. 2018, 6, 2630-2640.

49Rideout, D. C.; Breslow, R.; J. Am. Chem. Soc. Hydrophobic acceleration of Diels-Alder reactions. 1980, 102, 7816-7817.

50 Breslow, R. Hydrophobic effects on simple organic reactions in water. Acc. Chem. Res. 1991, 24, 159-164. 
51 Lubineau, A.; Bienayme, H.; Queneau, Y.; Scherrmann, M.-C. Aqueous cycloadditions using glyco-organic substrates. Thermodynamics of the reaction. New J. Chem. 1994, 18, 279-285.

52 Lubineau, A.; Auge, J.; Queneau, Y. Water-promoted organic reactions. Synthesis 1994, 8, 741-760.

53 Denis, C.; Laignel, B.; Plusquellec, D.; Le Marouille, J.-Y.; Botrel, A. Highly regio- and stereoselective reductions of carbonyl compounds in aqueous glycosidic media. Tetrahedron Lett. 1996, 37, 53-56.

54 Denis, C.; Misbahi, K.; Kerbal, A.; Ferrieres, V.; Plusquellec, D. Epoxidation of allylic alcohols in aqueous solutions of non surfactant amphiphilic sugars. Chem. Commun. 2001, 2460-2461.

55 Bellomo, A.; Daniellou, R.; Plusquellec, D. Allylation of cyclohexanones in aqueous media and influence of facial amphiphilic fructopyranosides. Tetrahedron Lett. 2010, 51, 4934-4936.

56 Bellomo, A.; Daniellou, R.; Plusquellec, D. Aqueous solutions of facial amphiphilic carbohydrates as sustainable media for organocatalyzed direct aldol reactions. Green Chem. 2012, 14, 281-284.

57 The SEPPIC company received in 2013 the medal of the Pierre Potier prize for chemistry innovation for sustainable development, for launching heptyl glucoside, a 100\%-bio-based solubilizer. 
58 Spiccia, N. D.; Border, E.; Illesinghe, J.; Jackson, W. R.; Robinson, A. J. Preparation of a nylon-11 precursor from renewable canola oil. Synthesis 2013, $45,1683-1688$.

59Vu, N. D.; Bah, S.; Deruer, E.; Duguet, N.; Lemaire, M. Robust organocatalysts for the cleavage of vegetable oil derivatives to aldehydes through retro-benzoin condensation. Chem. - Eur. J. 2018, 24, 8141-8150.

60 Deruer, E.; Duguet, N.; Lemaire, M. Thiazolylidene-catalyzed cleavage of methyl oleate-derived $\alpha$-hydroxy ketone to the corresponding free aldehydes. ChemSusChem 2015, 8, 2481-2486.

61 Lundin, M. D.; Danby, A. M.; Akien, G. R.; Binder, T. P.; Busch, D. H.; Subramaniam, B. As a safe and benign solvent for the ozonolysis of fatty acid methyl esters. ACS Sustainable Chem. Eng. 2015, 3, 3307-3314.

62 Louis, K.; Vivier, L.; Clacens, J.-M.; Brandhorst, M.; Dubois, J.-L.; De Oliveira Vigier, K.; Pouilloux, Y. Sustainable route to methyl-9-hydroxononanoate (polymer precursor) by oxidative cleavage of fatty acid methyl ester from rapeseed oil. Green Chem. 2014, 16, 96-101.

63 Omonov, T. S.; Kharraz, E.; Foley, P.; Curtis, J. M. The production of biobased nonanal by ozonolysis of fatty acids. $R S C A d v \mathbf{2 0 1 4}, 4,53617-53627$.

64Friberg, S. E. Hydrotropes. Curr. Opin. Colloid Interface Sci. 1997, 2, 490-494.

65 Molinier, V.; Aubry, J.-M. Sugar-based hydrotropes: preparation, properties and applications. Carbohydr. Chem. 2014, 40, 51-72. 
C-C bond-linked bio-based surfactants were prepared by direct aldolization of unprotected fructose with a range of fatty aldehydes.
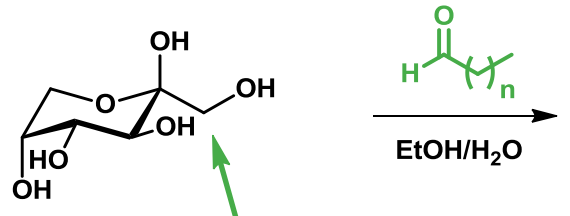<smiles>CCCCCCCCCCCC(O)C(O)C1(O)OCC2(O)COC1C2O</smiles>

alkylation site 